\title{
Albania Today and then: The Drivers to Growth
}

\author{
Shukran Qazimi \\ Mergleda Hodo
}

Doi:10.5901/ajis.2013.v2n3p413

\begin{abstract}
This study seeks to analyze Albania before and after the 90's, the present situation and the consequences of theStalinist regime. The first part of the paper examines Albania's milestones of the past, mainly EnverHoxha's communist regime and his economic policies until 1991; how it started, and how it evolved until its end.Then, it will describe Albania after the breakdown of communism, which still had to handle and manage multiple problems while traversing from one stage to another - the train of transition and the internal and external difficulties that come with it. One of the most essential elements of this analysis is the part of the incentives to economic growth. Questions to visualize about: Does the society save and are those savings applied to effective investments? Is the population growth modest? Are the policies stable, robust and effective in application? Is the country open to international trade, international capital flow, the movement of people, and the movement of information (knowledge)? The paper concludes that Albania has a bright future forward despite all the adversities it went through. By adding proper education to economic development, Albania will be the country of entrepreneurs, filled with sundry opportunities.
\end{abstract}

Keywords: Communist regime, Autarky, Socialism, Liberalization, Economic Growth and Albania.

\section{Introduction - Hoxha's Era}

Albania is a country located in Balkan Peninsula, in Southeastern Europe, one of the oldest nations in the region with a very rich history, a history full of hardships and sacrifices. It has often been taken as the example of Europe's pooresteconomy, among thirty two least developed countries in the world due to its self-isolation during EnverHoxha's catastrophic reign and economic policies until 1991. For 45 longyears the country has followed Marxist and Leninist economic practice.

Communism in itself contained many rules: every child from age 16 was obliged to work at least 8 hours; an adult by age 25 more than 15 hours per day, each family was constrained to donate all their properties to the government in order to create a cooperative. Instead of taking the monthly salaries they took the necessary food. Each family was forced to obey the law and the rules because in case they opposed the government then those people would be ferociously condemned.

The agriculture and industrial activities were totally diminished because of the "socialist economy", which played a very important role; the private land was forbidden, as well as private enterprise, agriculture was collectivized and everything was based on five-year plans. The population did not have the right to produce or cultivate for their own benefits. Another important "model" of the Albanian economy was the centralization and the refusal of the private sectors. Tourism, transport, construction, poorly built roads,telecommunication and other needs decreased the standard of living in Albania. The constitution, which was amended back then, prohibited the state from seeking any kind of foreign aid, including loans from various global financial institutions and, no foreign direct investment in the country was allowed. All of these contributed to transforming the country into one of the most isolated in the world. Nonetheless, attempts to transform into autarky or self-reliance badly failed in practice, as one would imagine in theory.

In February 1967religion was officially banned and Albania became the first and the only atheist country in the world.2035 religious buildings were closed or destroyed. Thousands of priests and imams were arrested and jailed. Everything regarding religion was prohibited, even mentioning the church was a way to end up in prison.He turned his beautiful country into a prison nation; most of the families were heavy persecuted, interned and killed.

EnverHoxha's vision was to kill the freedom of the Albanian people and to destroy their communal soul in order to build a totalitarian state under the rule of his single party. His regime applied threat and fear in every household, danger of strangers, danger of authority and even from family, friends and relatives seeking favors from the communist party. It created an inhuman lack of trust in everything and everyone. Faith in one another was totally lost; hater for one another became a way of life. A husband could not trust his wife, a parent his children, and a brother his sister. 
In the mid 90s, Albania became a liberalized economy. Like every fairytale, this one had a happy ending as well. After Hoxha's Era Albanians managed to see beyond the limits. Everything started gradually to change, a new life was born. Even though life after turbulent forties was hard to get on track, only the freedom was given to people. Albanians were seeking to find the way to survive and being optimistic that one day things will change for the better.

\section{President Sali Berisha in Power (1992- 1997)}

The first government that was democratically elected in 1992 had planned some major reforms in the economic sector, which included transforming it from a communist one to an open-market economy. Privatization (private sector activities), reforms in the financial sector, enterprise, were components of the launched program.

1993 was dedicated to the stabilization, to the emergent situation of the macroeconomic inequality, but still the country could not succeed because of the deep crisis, due to Albanian's inherent balances. Privatization, employment and the labor market started to open its doors. Services, transport, agriculture, small and medium-sized enterprises were privatized, until 1995 when large state owned enterprises started going through the same process. Some great results related to the GDP growth were on the horizon, as a consequence of the changes that occurred.

Change was one of the most difficult challenges for the population during that time because they were not used to manage work individually, revenues were below zero and everything had to start from the beginning. Then, external and internal difficulties had tremendous influence because people had not experienced. The time that they were shed of that miserable period they started to have multifold problems trying to balance the inner situation by moving from one country to another in order to find themselves.

May 1996 was the first time throughout Albanian history when Tirana Stock Exchange started to operate. This was a positive momentum, because the exchange rates became more stable.

\section{Albanian Rebellion 1997}

Everything seemed to be going well up until 1997. Many citizens,took their protest to the streets in order to get the money back. After the opening of the weapon depots, it was estimated that every male from the age of ten upwards possessed at least one firearm which actually triggered a civil war that lead to thousands of deaths and this phenomenon was called the "Cursed march".

\section{Nano's Period: 1997-2005}

For 46 years the communist party, ruled over a "party state" official forbiddance for all other political parties and organizations. After the communism period a multiparty system was established. The transition from one party system to a political pluralism was associated with the emergence and prospering of a large number of parties. The enthusiasm and the desire of Albanians for this new kind of freedom has drastically reflected due to the fact that around 57 parties were formed, a huge number for a small population size (three million inhabitants). Despite the large number of political parties only two of them have been described as being in practice. The Socialist Party on the left and the Democratic Party on the right.

The Socialist Party was in power since 1997 until it lost in 2005 elections. But during those 8 years it remains the best organized party in the country for several reasons: a modern, progressive party, a nationwide network. The main element was the adoption of the market economy. The government policies during 1997/99 tended to create more favourable conditions for foreign businesses. After stabilization, liberalization and opening state borders, people started to move from one country to another, in order to understand how the world functions. By then, the economy started to change colour. However, even though it was categorized as one of the fastest growing economy, Albania was still considered as among the least developed states in Europe. Albania is still on its way to major macroeconomic restructuring, which will lead to fundamental reforms. That is why Albania was among three countries in Europe (together with San Marino and Liechtenstein) to have economic growth after the global financial crisis hit.

\section{Berisha's Period: (2005- 2013)}

After the defeat of the Socialist Party, the Democratic Party comes on top whose aim was the introduction of a free market and a European future for Albania. Progress was continuing; schools, private universities, new banks, 
kindergartens were opened. Civilization had started to take roots; people had started to travel, to understand what the ideal thing to do was.

Immediately after the collapse of the communist regime Albania gained membership in the Conference on Security and Cooperation in Europe. It had a great effect, because this membership made Albania eligible for funding under EU programmer, it made possible a lot of aids to reach Albania.

The path towards EU for Albania continued regardless of the changes of governments. In 1999,EU proposed for Albania and for other countries the Stabilization and Association Process (SAP) and also a lot of benefits from Autonomous Trade Preferences with EU. It continued also with an extension of duty free market for Albanian products. A lot of improvements for an ex-communist country related to a free market economy and a free movement of goods between Albania and EU.

In 2006 Stabilization and Association Process is officially confirmed and countries whichparticipate in SAP were eligible for EU accession and may join EU once they are ready.

As a matter of fact it is true that Albania has made a huge progress in different measures such as rule, of law, democratic values, business freedom and even becoming part of NATO was a great success.

In 2010 the visa facilitation agreement entered into force. It was an important step which allowed Albanian citizens a free movement into EU member countries.

Related to democracy, the elections of 2009 would bring a new coalition with Democratic Party of SaliBerisha and Socialist Movement for Integration of Ilir Meta coming together and forming the new government. It was the first time in Albanian democracy that such a coalition to be shared together, a left party together with a right party. This is a clear example showing that democracy in Albania has evolved and also parties have started to become more pragmatic.

\section{Key Drivers of Economic Development}

Albania is still on its way to major macroeconomic restructuring, which will lead to fundamental reforms. That is why Albania was among three countries in Europe (together with San Marino and Liechtenstein) to have economic growth after the global financial crisis hit. But the idea is that the economy will never walk alone. Safety, order and state rules, all these elements influence each other, in order to make an economic progress of the country. These are the cornerstone to further economic development of a country.

There are many factors that positively or negatively affect the economic growth of a country. The questions that should be taken into consideration as a precondition for the growth are:

- Does the society save and are those savings applied to effective investments?

- Is the population growth modest?

- Are the policies stable, robust and effective in application?

- Is the country open to international trade, international capital flow, the movement of people, and the movement of information (knowledge)?

These are the key determinants which, actually, indicate growth in economic sense. Technological development, human capital, advanced infrastructure which is indispensable, low interest rates, developed banking sector, prices, real salaries, business and consumer confidence, political stability, these all add to the development in the long run.

Despite the public debt, about which the last report by Eurostat for EU and by CIA's World Factbook 2012 shows that Albania has had a $60.6 \%$ public debt as percentage of GDP, Albania's economy has improved over the last decade. A number of reforms have been achieved in the development of infrastructure, law on property, tax collection, and business administration. As far as the global financial crisis is concerned, Albania has outperformed many countries in the region, even though it continues to be one of the poorest countries in Europe. It has a fairly high unemployment, corruption, strong crime networks, and violent political opponents. The investments depicted as a percentage of GDP, according to EconomyWatch.com's Econ Stats database, are 22.859 \%. The Gross National Savings (\% of GDP) 13.419 $\%$. A lot of investments are being made in projects such as: Albania MDTF for Extractive Industry Transparency Initiative (EITI), which is in the 3rd phase of implementation, the Water Resources and Irrigation Project, the privatization of the Power Distribution System Operator (OSSH) Partial Risk Guarantee, youth empowerment through community development in Albania, the social assistance modernization project etc.

Albania's population was estimated to be $3,002,859$ in July 2012 . The population growth was $0.28 \%$. Economic growth is largely dependent on population growth, as defined by the gross national product. In order to accommodate the needs of more and more people, we need more jobs and more products and services. However, the GNP cannot grow indefinitely in a world with finite resources. 
Since Albania has submitted an application to join the EU, in 2012 there has been some progress in coordinating processes for aligning legislation with the EU acquits. However, according to a publication made by the European Commission, there is still a gap in the policy-making and the processes of drafting legislation in ministries because of the lack of transparency. The quality of the drafting of legislation has also been impeded by the weak analytic capacity and high staff turnover. That is why more attention should be paid to the implementation and enforcement of legislation. According to the same publication, Albania has only had moderate progress regarding the coordination of the EU integration process, no progress was made on territorial administrative reform, There was no improvement in revenue collection by local authorities. Albania is expected to pay attention to areas of strategic planning, human resources management and financial control, it should put forth effort to ensure transparency and formulate a strategic approach in funding various municipal projects.

Albania joined the World Trade Organization in September, 2000. Since then, this past decade, Albania has been ambitious in its economic, institutional, and legal reforms. This ambition has been driven by the country's strong desire to join the European Union. In order to sustain a well-functioning market economy Albania has enacted a series of laws. It has signed the Stabilization and Association Agreement (SAA) with the EU which not only commits on liberalizing the trade between Albania and the EU, but also it also contains a number of provisions that are designed to help Albania align its laws with EU laws. What initially was a closed economy has now become a market and private-sector oriented, liberal economy. As the official government report states: "Assessments and economic developments confirm that the Albanian economy during the last decade was characterized by a high and sustainable economic growth. Economic developments of this decade reflect the economic transformation and restructuring processes, coupled with "positive and negative factors" in certain years, towards an economy based on market mechanisms and free initiative".

\section{Conclusion - Albania Tomorrow}

Since "the League of Prizren" which happened in 1878, up until today, Albanians of all generations wanted to join Europe. "We want to become like Europe". More concretely, this means that Albania should split from its deep dark past in order to become a robust, profitable, rich and equal partner to Western European friends and allies.

Politically speaking, the first thing that is disturbing is the political instability, and the duress the two biggest parties put each other through has consequences on the whole country. I believe that this issue will be overcome, since it's in everyone's benefit that it happens so. Another issue that is of crucial importance to the political and economic progress of the country is the joining the EU which will provide Albania with a substantial financial assistance, and overall economic stability. Of all states wishing to join the EU, the "Land of the Eagles" seems to be more motivated than most. But, the chance of obtaining candidate status at the moment is pretty slim, because there is so much progress yet to be made.

Another issue that I see has had progress in the future is the gender role issue that has been present in Albania. The patriarchal paradigm has been part of our society since forever, actually, which has caused women to be treated as inferior to men. For years, women have been taken away the possibility of building themselves in both their careers and personal lives. This country could have benefited from women long ago, if it had not been too blind to see that women are as important to the workforce and as important citizens as men. In the future, I believe that women will free themselves of this societal paradigm, and will stand up for themselves; not only for themselves and other women but also for the whole country and the future of their children. In the future, they will be working hard and many women will be entrepreneurs of their own firms and will provide the society with products and services and will successfully run them, that way helping the country achieve prosperity.

In the future I have pictured Albania as a part of the European Union, enjoying the total benefits of being in it. The political system is stable and all parties are working together to achieve common goals in the interest of the beloved homeland, however impossible that may sound at the moment.

Having tons and tons of beautiful and incredible places that have unfortunately not been displayed to people outside the country because of a lack of funds, Albania's richness in ancient ruins can pave the way to prosperity for the country's tourist industry. Tourism, in the future that I imagine, has improved and now Albania is enjoying incoming funds from visitors and offering them the enjoyment of both its summer and winter tourisms. The shores of Vlorë and Sarandë, and the mountains throughout the country, the historical sightings and ruins are becoming more and more often visited and treasured by, both, the natives and outsiders. The building of the highways and roads will be done and will enable the tourists to better reach Albania. Natives will be more eager to visit relatives outside Albania, and those relatives will start visiting the natives of Albania as well.

Overall, the Albania I see in the future is a better Albania. An Albania that tries its hardest to become better with 
each passing day.An Albania that fights for its rights, for its citizens.An Albania that never gives up on hope and the possibility of improving itself. That is the way I see it, and that is the way most Albanians do, because we believe in hard work, justice, in the power of the given word, in the strength of brotherhood. These are the values we have always stood up for, and these are the same values we will always continue to encourage. These are the values that make us who we are. Now, I believe, all that is left for me to say is: "Cheers! To a Better Albania".

\section{References}

Sievers, S.S. \& Fischer J. B. ( 2002, January). Albanian Identities: Myth and History

Muço, M. (1997, June).Economic transition in Albania: Political constraints and mentality barriers. Retrieved from: http://www.nato.int/acad/fellow/95-97/muco.pdf

Civici, A. (2012, November 28 ).Ekonomiashqiptaregjatëregjimitkomunist(1945-1990).Retrieved from: http://www.monitor.al/100-vjetekonomia-shqiptare-gjate-regjimit-komunist-1945-1990/

Fischer, B.(2012). Albania since 1989: The Hoxhaist Legacy. Retrieved from: http://www.festirana.org/media/publications/pdffiles/ 2012/pub_shqiperia_ne_dhjete_vitet_e_ardhshme_english.pdf

Rakipi,A. (2012). Albania in the Next Ten Years-An Agenda for Change 5-8. Retrieved from: http://www.festirana.org/media/ publications/pdffiles/2012/pub_shqiperia_ne_dhjete_vitet_e_ardhshme_english.pdf

Archives, L. (2012, August 23). Un documentario del isitutolucecheracconta la storiad'Albaniadaglianni 1890 a 1990 (Video File). Retrieved from: http://www.youtube.com/watch?v=IGY1IUP_U-Q

Fevziu, B. (2012, May 4). Dokumentari per EnverHoxhen-Diktatori (Video File).Retrieved from: http://www.youtube.com Iwatch?v=x5EqTTBSgy4

Crepo-Redikor, H.(2013, June 24).Women as a driver of economic growth (Video File). Retreived from: http://www.iie.com/events levent_detail.cfm?EventID=288

Saville, A. (2013, January 31). The drivers of economic growth (Video File). Retrieved from: http://www.youtube.com I watch?v=VzZDDgagmVA

Albanian 2012 Progress Report [APR],2012 Retrieved from: http://ec.europa.eu/enlargement/pdf/key_documents 12012/package/al_rapport_2012_en.pdf

Goldstein, Ellen. (2013, August 29). Next Generation Albania - Shaping a New Model for Economic Growth. Retrieved from: http://www.worldbank.org/en/news/speech/2013/08/29/goldsteinremarksforalbanianconference

Trade Policy Review [TPR], 2010 Retrieved from: http://www.wto.org/english/tratop_e/tpr_eltp329_e.htm

Austin C.R. (2012). First and Second Starts: Albania After World War One and After Communism. Retrieved from :http://www.festirana.org/media/publications/pdf-files/2012/pub_shqiperia_ne_dhjete_vitet_e_ardhshme_english.pdf

Kaduku, I. (2012, February). The Past, the Present and the Future of the Albanian Tourism. Retrieved from: http://www.scientificpapers.org/wp-content/files/1218_llir_Kaduku_The_Past_the_Present_and_the_Future_of_the_Albanian_ Tourism.pdf

The European Union in Albania [EUA], Albania a future with Europe - sharing common values to build a common future. Retrieved from: http://ec.europa.eu/enlargement/archives/seerecon/albania/documents/albania_future_with_europe.pdf 
